\title{
Effect of new livestock feeds' phytonutrients on productivity, carcass composition and meat quality in pigs
}

\begin{abstract}
Improving pig growth performance, nutrient digestibility and pork quality is a continual goal of the pig breeding. For this reason, an increasing interest in using phytonutrients has been observed recently. The objective of this study was to determine the impact of Larix sibirica dihydroquercetin or dry distilled Rosa damascena petals on growth performance, carcass composition, meat quality, blood characteristics and histological changes in ovaries and liver in native Danube White fattening pigs. A total of 120 pigs were used in the experiment with duration of 45 days prior to harvest. The pigs were divided into five groups. The control group (C) was fed basal diet. The other four experimental groups were fed with the same diets containing either 3.5 or $7.5 \mathrm{mg}$ dihydroquercetin $/ \mathrm{kg} / \mathrm{d}$ and 0.255 or $0.545 \mathrm{~g}$ dry distilled rose petals $/ \mathrm{kg} / \mathrm{d}$. The supplementations with dihydroquercetin or dry distilled rose petals increased average body weight by $7.74-9.05 \%$, average daily gain by $27.06-30.13 \%$, and feed to gain ratio by $12.53-15.99 \%$ and decreased feed consumption by $5.24-13.84 \%$ and average liver weight by $10.53-21.12 \%$ compared to the control group. Two supplementations didn't cause pathological changes in histological structure of pigs' liver and ovaries, and didn't influence $\mathrm{pH}$ values and proximate composition of $\mathrm{m}$. Longissimus thoracis and $\mathrm{m}$. Semimebranosus. No pH determined stress-induced muscle damage was found and the pork carcasses were classified in classes E and U. The two used supplements reduced the blood LDL cholesterol by 13.27-14.29\% as well as increased erythrocytes, platelets, haematocrit, mean red blood cell count, mean haemoglobin concentration in erythrocytes, triglycerides and total cholesterol.
\end{abstract}

Keywords: Danube white pigs, dihydroquercetin, dry distilled rose petals, growth performance, blood parameters, ovaries and liver histology 
The improvement of livestock production performance by including of plant-derived compounds in diets and promoting animal health and pork quality has been discussed last years (Guil-Guerrero et al. 2016). A number of approaches have been explored to increase the production of high quality pork (Valenzuela-Grijalva et al. 2017). Lebret (2008) offers the nutritional quality of pork to be improved by modification of fatty acid composition and antioxidant level in meat. For this purpose, the diet supplementation include vegetable sources with high n-3 fatty acids (Lebret 2008), essential oils (Yan et al. 2010), herbal plants and their derivatives (Hashemi and Davoodi 2011), herbs and spices (Frankič et al. 2009) and their extracts (Liu et al. 2008), organic acids (Costa et al. 2013), dried fruits and vegetable pomaces (Pieszka et al. 2017) have been discussed.

The dihydroquercetin (DHQ) is a flavonoid (Weidmann 2012), a good electron donor, which may inhibit hydroxyl radicals (Chen et al. 2002) and has radioprotective, membraneprotective, capillaryprotective, angioprotective, lipidreducing, anti-inflammatory, antiallergic, cardioprotective, hepatoprotective, detoxifying, neuroprotective, gastroprotective, immunomodulatory, retinoprotective and endocrinological properties (Artem'eva et al. 2015). The benefits of dietary DHQ on immunodeficiency, bronchopulmonary diseases and liver function have been published too. Analysis of stereoisomeric composition demonstrated two bioflavonoids derived from Siberian larch (Larix sibirica) (Kolesnik et al. 2011). Fomichev et al. (2016) put attention on the potential of the preparation "Ekostimul-1" which contains 1.0-2.0\% of natural bioflavonoid DHQ and pulp of Dahurian larch (Larix dahurica Turez). As a result of its healthy effects Fomichev et al. (2016) supposed that $1-5 \mathrm{~g}$ Ekostimul-1/kg/d supplementation in combination with various probiotics can be used for realisation of a productive potential of pigs under impact of stressfactors.

Another new potential beneficial phytonutrient is a by-product derived from rose oil production. Dry distilled rose (Rosa rugosa) petals (DDRP) contain a wide range of bioactive compounds that possess strong cytotoxic, antioxidant and antimicrobial properties (Nowak et al. 2014). The 13 glycosides of kaempferol, 10 glycosides of quercetin, 6 glycosides of gallic acid and 2 flavonol aglycones were identified in dry rose petals (Dragoev et al. 2020).

Balev et al. (2015) tried to explore the DDRP in broilers' feeding. Results of these studies suggested DDRP alters positively poultry meat composition. No information for use of DDRP as feed additive in pigs has been available.

Therefore, the objective of this study was to determine the impact of Siberian larch DHQ or DDRP on growth performance, carcass composition, meat quality, blood characteristics and histological changes in ovaries and liver in native Danube White fattening pigs.

\section{MATERIALS AND METHODS}

\section{Pigs and diets}

This experiment was conducted in accordance with Art. 14 of Part V. Breeding and Livestock Units form European Convention for the Protection of Vertebrate Animals used for Experimental and Other Scientific Purposes, Commission Recommendation 2007/526/EC and Council Regulation (EC) No 1099/2009. The experiment was approved by the Bulgarian Scientific Ethics Committee and requirements of the Council Directive 2010/63/EC were met.

A total of 120 Danube White 155 days old fattening pigs (both sexes - 60 male and 60 female) of $72.500 \pm 1.937 \mathrm{~kg}$ (mean $\pm \mathrm{SD}$ ) were used. They were housed in barn equipped 
with individual pens with feeders and drinkers, in facilities at the Experimental Farm of Agricultural Institute, Shumen, Bulgaria. During the experiment, the temperature was between 19 to $27^{\circ} \mathrm{C}$. Feed was available ad libitum. Water was provided by nipples drinkers ad libitum. The pigs were randomized by origin, age, sex, weight and distributed into five groups (one control and four experimental), each containing of 24 animals fed for 45 days with two different supplementations. The control group (C) was fed basal diet (Table 1). Bioconcentrates BK14 and BK16 included in the formulations of grower and finisher basal diets were supplied by Vasil Kostov Feed Factory, village Lyuben Karavelovo, Varna District, Bulgaria.

The other four experimental groups were fed with the same diets containing either $3.5 \mathrm{mg}$ DHQ/kg/d (D1), $7.5 \mathrm{mg}$ DHQ/kg/d (D2), $0.255 \mathrm{~g}$ DDRP/kg/d (R1) or $0.545 \mathrm{~g}$ DDRP/kg/d (R2). Residual feed was monitored daily and was weighed and subtracted from of the daily amount of feed consumed.

The dihydroquercetin was provided by the company Flavitlife Bio JSCo (Sofia, Bulgaria) and the distilled rose petals were supplied by Damascena rose oil distillery, village of Skobelevo, municipality of Pavel Banya, Stara Zagora district (Bulattars Production Company Ltd, Sofia, Bulgaria). After pressing, petals were dried and ground to particle size $<0.4 \mathrm{~mm}$.

Individual daily doses of the supplements were chosen based on follows: the dihydroquercetin antiradical activity manifesting in a concentration $0,0001-0,00001 \%$ (Fomichev et al., 2016); the concentration of natural bioflavonoid dihydroquercetin was recalculated taking into account the much higher purity (96\%) in the isolate used by us in this study compared to the significantly lower levels in the preparation "Ekostimul-1" (Fomichev et al. 2016) with an idea to be applied comparable concentrations of biologically active compounds; our experians for improving the oxidative stability of pork by of natural polyphenolic compounds (Vlahova-Vangelova et al., 2020) and observing the economic effect of the application of the preparations due to their very high price. Individual daily doses of the supplements were calculated according to previous weighing of animals, mixed with feed (Table 1) and given with the morning feeding.

Animals were weighed every two weeks. During the fattening period, the animals were reared in accordance with the requirements of Bulgarian Ordinance No 21 of December 14, 2005 on the minimum requirements for thr protection and human treatment of pigs. At the end of the experiment, the age of the pigs was 200 days and the live weight was at about 110.300 $\pm 2.274 \mathrm{~kg}$.

\section{Sample preparation}

The blood sampling was made in the beginning (on August 3, 2017) and at the end (on September 17, 2017) of the experiment. The blood samples were analyzed immediately after sampling. The 200 day old pigs were identified and transported to a processing plant (Unitemp Ltd, Voyvodinovo village, Plovdiv district, Bulgaria). After $18 \mathrm{~h}$ of pre-slaughter break, pigs were showered and harvested in accordance with requirements of the Bulgarian Ordinance No 15 of May 8, 2009 for qualification and classification of carcases of bovine, porcine and ovine animals on the EUROP Community scale following normal industry processing procedures. Carcasses were split and chilled. Ovaries from 60 female pigs and 120 livers were collected at harvest. After a $24 \mathrm{hr}$ chilled to $4^{\circ} \mathrm{C}$ carcasses were moved to a cold storage where they remained until fabrication. Samples of $\mathrm{m}$. Longissimus thoracis et lumborum (further called $\mathrm{m}$. Longissimus thoracis) and $\mathrm{m}$. Semimembranosus were removed from each carcass. Chilled muscle samples were ground through $3 \mathrm{~mm}$ grinder plates and mixed. The proximate 
composition analyses of grower and finisher basal diets, meat proximate composition and $\mathrm{pH}$ were determined as means after five replicates (Table 1).

\section{Determination of growth performance and liver weight}

The growth performance and liver weight were determined by weight measurements.

\section{Blood tests}

At days 155 and 200, pigs from the five experimental groups were immobilized and $10 \mathrm{~mL}$ of blood was extracted from the jugular vein of each pig. The blood samples were taken in vacutainer tubes using a California-type needle. In consequence, they were transferred to the laboratory within the first $3 \mathrm{hr}$ for further analysing. The blood profile analyses were done by differential hematology analyzer Abacus 5 (Diatron Medical Instruments PLC, Budapest, Hungary). They included determination of leukocytes (WBC) by conductometric and visual optical method, erythrocytes (RBC) by conductometric method, haemoglobin (HGL) by cianmethaemoglobin method, haematocrit (HCT) by indirect based on conductometric analyzes method, mean red blood cell count (MCV) by conductometric method, mean haemoglobin content in erythrocytes $(\mathrm{MCH})$, mean haemoglobin concentration in erythrocytes (MCHC) and erythrocyte distribution width according to their volume (RWD) by calculations, platelets (PLT) and mean platelets volume (MPV) by conductometric method following flotation of erythrocytes. The fat profile and glucose analyses were done by automated Olympus AU640 chemistry analyzer (International Equipment Trading Ltd., Mundelein, Illinois, USA) as follows: blood glucose content (GLU) using GOD/PAP Hexokinase/G-6-PDH method, total cholesterol (T CHOL) by enzymatic colorimetric CHOD-PAP method, triglycerides (TRIG) by enzyme colorimetric-GPO-PAP method, LDL-cholesterol (LDLs) and HDL-cholesterol (HDLs) through direct method. The blood estradiol concentration was measured by Roche Elecsys 2010 immunoassay analyzer (Roche Diagnostics, Bellport, New York, USA) using chemiluminescence immunoassay (CLIA) method. Blood was also taken once in 50 female pigs to detect estradiol content at the end of the experiment. Analytical procedures of blood tests were made following the Weiser (2012) recommendations.

\section{Histological imaging of ovaries and liver}

Samples from the from testicular tissue of male pigs were not taken because the animals were neutered.

For the morphological analysis, ovaries and liver tissue cuts with size $2 \times 1 \times 1 \mathrm{~cm}$ were placed in formalin, dehydrated sequentially in ascending order alcohols, acetone and xylol. After dehydratation, the samples were included in paraffin at $56^{\circ} \mathrm{C}$ for $24 \mathrm{hr}$. The paraffin blocks were cut into sections of approximately $5 \mu \mathrm{m}$ and contrasted with hematoxylin-eosin according to the methods described by Sultana et al. (2008). Microphotographs were performed with Nikon Microphot SA microscope (Nikon, Tokyo, Japan), combined with Camedia-5050Z digital camera (Olympus Corporation, Tokyo, Japan).

\section{Determination of $\mathrm{pH}$ as an indicator of stress-induced muscle damage}

The $\mathrm{pH}$ value in the m. Longissimus thoracis and m. Semimebranosus at $45 \mathrm{~min}, 24 \mathrm{hr}$ and 7d post mortem was measured with a laboratory pH meter MS 2004 (Microsyst, Plovdiv, Bulgaria) equipped with a temperature and combined $\mathrm{pH}$ electrode Sensorex $450 \mathrm{CD}$ (Sensorex, Inc., Garden Grove, USA) (Young et al. 2004). The potential stress-related muscular injuries were determined by the Warriss (2000) methodology. According to this theory, if the $\mathrm{pH}_{45 \mathrm{~min}}$ of $\mathrm{m}$. Longissimus thoracis is $5.8-6.4$ and $\mathrm{pH}_{24 \mathrm{hr}}$ is $5.3-6.0$ the pork 
meat is normal. Contrary to that if the $\mathrm{pH}_{45 \min }$ is $<5.8$ and $\mathrm{pH}_{24 \mathrm{hr}}$ is $<5.3$ the meat is pale pinkish red, soft and exudative (PSE). The opposite if the $\mathrm{pH}_{45 \min }$ is $>6.4$ and $\mathrm{pH}_{24 \mathrm{hr}}$ is $>6.0$ the meat is darkish red, firm and dry (DFD).

\section{Determination of lean meat content}

After the carcasses production, the thickness of the back fat at two points, the thickness of $\mathrm{m}$. Longissimus thoracis and lumborum and the percentage of lean meat, weight of warm and cold carcass, 1 and $24 \mathrm{hr}$ post mortem were measured. The Ultra Fom 200 apparatus (Carometec Food Technology, Harley, Denmark) was used. The apparatus is equipped with a $4 \mathrm{MHz}$ ultrasonic probe (Krautkrämer MB $4 \mathrm{SE}$ ). The ultrasonic signal is digitized, stored and processed by a microprocessor (Intel 80 C 32 type). Measurement results are automatically converted to lean meat content using the regression model:

$\mathrm{Y}=67.13-0.3284 \mathrm{X}_{1}-0.3725 \mathrm{X}_{2}+0.01515 \mathrm{X}_{3}$ where:

Y- lean meat content, \%;

$\mathrm{X}_{1}$ - fat of the fat and skin, measured at $7 \mathrm{~cm}$ from the midline of the carcase, between the $3^{\text {rd }}$ and $4^{\text {th }}$ lumbar vertebrae, $\mathrm{mm}$;

$\mathrm{X}_{2}$ - fat of the fat and skin, measured at $7 \mathrm{~cm}$ from the midline of the carcass, between the $3^{\text {rd }}$ and $4^{\text {th }}$ rib, mm;

$\mathrm{X}_{3}$ - thickness of $\mathrm{m}$. Longissimus thoracis measured at point $\mathrm{X}_{2}$.

\section{Determination of proximate composition of pork}

Moisture was determined by drying samples at $105^{\circ} \mathrm{C}$ (Keeton et al. 2003). Ash was determined as outlined (AOCS 2004) and total protein was determined by the Kjeldahl method (AOCS 2004), using the Automatic Distillation System Model UDK 152 (Foss Tecator AB, Hoganas, Sweden). The lipids were determined by weight after extraction with a non-polar solvent in the Soxhlet apparatus (AOCS 2004). Calcium and phosphorus were determined by the method described by Anwar et al. (2016). The minced defatted samples were decomposed by treatment with $\mathrm{HNO}_{3}$ and $\mathrm{HClO}_{4}$, after which the phosphate was removed by ion exchange column in the form of acetate. The $\mathrm{pH}$ of the stock solution was adjusted to 12.5 . Samples were titrated with disodium ethylenediamine tetra-acetate as an indicator until the color changes to pink-blue.

\section{Statistical analysis}

Statistical analyses were performed using different software packages Microsoft Excel 5.0; JMP, v.7 JMP v. 7 for Windows (SAS, Inc., Cary, NC, USA) and MINITAB 16 (Leman et al. 2013). The data were analysed statistically by ANOVA. The statistical differences between groups were denoted by different letter superscripts. Data are expressed as mean $\pm \mathrm{SD}$. Results were considered significant.

\section{RESULTS}

\section{Growth performance}

The pigs from the four experimental groups were found to have a higher final average body weight $(\mathrm{ABW})(\mathrm{p}<0.05)$ than the control group $\mathrm{C}$, as follows: pigs from group D1 by $9.05 \%$, from group R2 by $7.74 \%$, by R1 by $4.64 \%$ and by D2 by $3.81 \%$, respectively. They had a higher $(\mathrm{p}<0.01)$ average daily gain $(\mathrm{ADG})$ too, in comparison to the control group $\mathrm{C}$ as 
follows: in group D1 the ADG was higher by $30.13 \%$; in group R2 by $27.06 \%$; in group R1 by $15.48 \%$, and in group D2 by $13.11 \%$, respectively (Table 2). Two studied phytonutrients reflected the feed consumption and feed to gain ratio, too. The use of the studied supplementations resulted in an increase in the amount of feed intake between $5.24 \%$ and $13.84 \%$. The best feed utilization was found in the group D1 and group R2. Significant differences were found between two groups supplemented by DDRP $(\mathrm{p}<0.05)$. Those results proved the better efficiency of the higher concentration of $545 \mathrm{mg}$ DDRP compared to the lower concentration of $255 \mathrm{mg}$ DDRP, where gaining of $1 \mathrm{~kg}$ body weight was realized by $0.297 \mathrm{~kg}$ less feed. Similarly, the lower concentration of $3.5 \mathrm{mg}$ DHQ has better efficiency compared to the higher concentration of $7.5 \mathrm{mg}$ DHQ, where gaining of $1 \mathrm{~kg}$ body weight was realized by $0.228 \mathrm{~kg}$ less feed. The difference in the parameter feed to gain ratio between the control and experimental groups was the most pronounced for group R2 (15.99\%) followed by group D1 (12.53\%), group R1 (8.71\%) and group D2 (6.97\%), respectively (Table 2).

\section{Blood parameters}

The feed supplementation with the DHQ or DDRP doesn't affect the amount of WBC, HGL, MCH, MPV, GLU and HDLs in the blood of pigs (Table 3). The pigs from group D2 didn't have statistically significant differences $(\mathrm{p} \geq 0.05)$, compared to the pigs from the control group $\mathrm{C}$ in these blood parameters. It was found the supplementation of $0.545 \mathrm{~g} \mathrm{DDRP} / \mathrm{kg}$ body weight (group R2) reduced RBC by $1.13 \%$ and PLT by $20.34 \%(\mathrm{p} \leq 0.05)$ in comparison to control group $\mathrm{C}$. An even more pronounced significant $(\mathrm{p} \leq 0.001)$ reduction was found for the HCT - with $12.19 \%$, MCV - with $10.95 \%$ and MCHC - with $3.02 \%$. In group R1 a significant increasing ( $<20.05$ ) in RBC by $1.61 \%$, PLT by $2.58 \%$, T CHOL by $10.85 \%$, HCT by $4.88 \%$, MCV by $2.74 \%$, RWD by $10.72 \%$, TRIG by $10.81 \%$, and MCHC by $6.06 \%$ (p < 0.001 ), compared to control group C, was found. At the same time, the LDLs was reduced by $13.27 \%$ ( $p<0.01$ ). The most pronounced changes were established in the blood samples from the group D1. Compared to control group C, a significant increase $(\mathrm{p}<0.05)$ in RBC by $4.35 \%$, PLT by $15.61 \%$, T CHOL by $13.57 \%$ and a significant increase (p < 0.01$)$ in HCT by $7.32 \%$, MCV by $3.80 \%$, MCHC by $11.45 \%$, RWD by $25.60 \%$ and TRIG by $18.02 \%$ was observed. In the same time LDLs was reduced by $14.29 \%(\mathrm{p}<0.01)$.

The very strong decreasing of the hormone estradiol in the blood samples between the control and experimental groups was established (Table 3). In experimental group R2 the estradiol level was reduced approximately 8 times and in experimental groups D2, D1 and R1 - about 2 - 2.5 times.

\section{Liver weight and histology of ovaries and liver}

The lowest average liver weigh $(\mathrm{p}<0.01)$ was measured in pigs from group $\mathrm{R} 1$, followed by groups D1. The ratio of average liver weight (ALW)/final ABW x 100 in pigs from group $\mathrm{R} 1$ was lower by $21.12 \%$ and from groups D1 by $10.53 \%$ lower in comparison to control group C. No significant differences were found in the ALW and ALW/ABW ratio in pigs from groups D2, R2 and C (Table 4). The lower levels of two studied supplements contributed to the reduction of liver weight. It is observed well preserved liver structure of classical hepatic lobule with centrally located vein (v. centralis). Preserved cytoarchitectonics, radially located hepatocytes on hepatocyte lamellae were found. The portal spaces formed by an arterial vessel, a venous vessel and a bile duct were normally located in the periphery of the lobules. No pathological changes in liver structure, no fibrinoid accumulation and no fatty degeneration (hepatic steatosis) were observed. There were no visible intracytoplasmic accumulations of triglycerides. No defective remodelling of the ductal plate or abnormal branching of the 
intrahepatic portal veins, no regressive fibrosis of portal tracts Anastomosing biliary channels in regular, hepatocyte nodules with central veins and normal architecture were detected. No marked proliferation of bile ductless, no angulated bile ducts, no inflammation, and no regenerative nodules were observed (Figure 1). Preserved thick connective tissue capsule - the tunica albuginea of ovaries, covered by a simple squamous mesothelium - germinal epithelium, was found.

A cortex, with the ovarian follicles, and a highly vascular medulla with coiled arteries called helicrine arteries, were found (Figure 1). The oocytes were surrounded by epithelial cells and formed follicles. It contained many primordial follicles which were mostly found around the edges of the cortex. There were fewer follicles with histological appearance in different stages of development (Figure 1).

\section{The lean meat content}

The values of the variables involved in the models for determining the relative proportion of lean meat in the carcass indicated pigs consuming higher doses of the two studied supplements (groups R2 and D2) were characterized by a thinner fat at the two measurement points (Table 4). The pigs from the groups R2 and D2 were classified in class E and those from the other three groups - to class U under the SEUROP system. On the other hand, the deviations of lean meat content were not significant $(\mathrm{p} \geq 0.05)$ and ranged between 52.83 $55.07 \%$ (Table 4).

\section{pH determined stress-induced muscle damage}

No significant differences $(\mathrm{p} \geq 0.05)$ between $\mathrm{pH}$ values of the two muscles of the five examined groups $45 \mathrm{~min}$ post mortem, and after 7 days of storage at $0-4^{\circ} \mathrm{C}$ were found. Conversely, $24 \mathrm{hr}$ post mortem in $\mathrm{m}$. Longissimus thoracis the significantly lowest $\mathrm{pH}$ values $(\mathrm{p}<0.01)$ were examined in the groups $\mathrm{R} 2, \mathrm{D} 1$ and $\mathrm{R} 1$. The highest $\mathrm{pH}$ value $(\mathrm{p}<0.05)$ was determined in control group $\mathrm{C}$. The difference in the mean values between the lowest and the highest $\mathrm{pH}$ level was about $2.5 \%$ or $0.15 \mathrm{pH}$ units. Similar $\mathrm{pH}$ values were determined in $\mathrm{m}$. Semimembranosus. Significant differences $(\mathrm{p}<0.05)$ in the $\mathrm{pH}$ values were found $24 \mathrm{hr}$ post mortem. The deviation of $\mathrm{pH}$ levels was only $1.92 \%$ or $0.11 \mathrm{pH}$ units (Table 5). According to Warriss (2000) our results didn't indicate the stress-induced muscle damage. The pork from all studied groups was classified as a normal.

\section{Proximate composition of pork muscles}

The DHQ or DDRP supplementations didn't influenced ( $\mathrm{p} \geq 0.05)$ the content of water, proteins, fats or mineral substances in the studied pork muscles (Table 6).

\section{DISCUSSION}

The polyphenols have beneficial health effects on the brain, blood vessels, muscles and intestines (Kawabata et al. 2015). The pigs' growth performance was positively influenced by the supplementation of DHQ or DDRP due to their properties being good stimulators of animal appetite and accelerators of the metabolic processes (Valenzuela-Grijalva et al. 2017). This was a reason of receiving higher $\mathrm{ABW}, \mathrm{ADG}$ and feed consumption, and lower feed to gain ratio in experimental groups in comparison to control one. Our results about DHQ supplementation effect on the ADG were similar to those reported by Fomichev et al. (2016). The DHQ has strong antioxidant activity and capillary protection (Miller and Ruiz-Larrea 2002). It may 
intensify anabolic processes and may increase the ADG in pigs (Bogolyubova et al. 2019). The DHQ solutions effectively suppresses facultative pathogens, being without negative effects on intestinal probiotic microflora (Artem'eva et al. 2015). It has good solubility in the intestinal tract due to generation of chylomicrons in the intestinal mucosa (Lesser et al. 2006).

Furthermore, the DDRP contain wide range of flavonoids (Schieber et al. 2005) that possess strong antioxidant properties but unlike the DHQ they are not a purified substance. In order to exhibit biological activity, the dose taken should be relatively higher. The DDRP stimulate better feed utilization in later stage after the beginning of the supplementation. It is likely that the pigs' organism needs some time to accumulate the DDRP biologically active components in order to show their positive influence. Probably those phenomena may explain the best feed utilization in group R2. The established 13-14\% blood LDLs reduction in groups R1 and D1 was probably due to the cooperation between supplemented flavonoids (DHQ and DDRP) with the antioxidative vitamins $\mathrm{C}$ and $\mathrm{E}$ in the blood stream and maintaining its redox state. In a result the susceptibility of LDLs to oxidation was reduced (Miller and Ruiz-Larrea 2002). Contrary to reported by Pitoyo and Fatmawati (2012) statement that $50 \mathrm{mg}$ quercetine $/ \mathrm{kg}$ reduced blood glucose and triglyceride levels in rats, our study didn't found significant differences between blood glucose levels in $3.5 \mathrm{mg} / \mathrm{kg}$ DHQ and $225 \mathrm{mg} / \mathrm{kg}$ DDRP supplemented pigs comparing to control group C. In the same time, the TRIG and T CHOL increasing in groups R1 and D1 suggested that effects of DHQ and DDRP were dosedependent. Probably the DHQ and DDRP polyphenols positively modified lipoprotein profile, didn't change the fattiness of liver and ameliorate an antioxidant status in blood circulation (Škottová et al. 2003). The potent hepatoprotective activity of DHQ and DDRP could be assumed due to the lower relative liver weight in groups R1 and D1. It could be explained with inhibition of lipids free-radical oxidation which caused an increasing of antioxidant protection of cell membrane phospholipids of liver tissue cells during the pigs fattening period (Bogolyubova et al. 2019). The flavonoids such as DHQ improved lipid accumulation, inflammatory response and the levels of cellular antioxidants in liver (Kawabata et al. 2015). In vivo flavonoids had ability to influence various enzymes and their antioxidant properties (Manach et al. 2005).

The hormone estradiol is the biologically most active estrogen mainly formed by the ovarian follicles of the yellow body (Reed and Carr 2018). Estradiol levels increase during the follicular phase and depend on the growth and development of the ovarian follicle (Kevenaar et al. 2007). They increase by the time of ovulation, and again when the yellow body is formed and decrease at the end of the menstrual cycle (Reed and Carr 2018). This can explain the large deviations of estradiol in the blood.

The determined $\mathrm{pH}_{45 \min }$ and $\mathrm{pH}_{24 \mathrm{hr}}$ values of two studied muscles didn't indicate stressinduced muscle damage. The meat quality and nutritional value depended on the ratio of its chemical constituents (Culioli et al. 2003) which was an evidence that the used phytonutrient supplementations had no effect on the proximate composition of pork m. Longissimus thoracis and $\mathrm{m}$. Semimebranosus. We suppose this was due to intramuscular fats in studied Danube white pigs were less than $1 \%$ (Wood et al. 2008).

\section{CONCLUSION}

The supplementation of Danube white pigs' feed with $3.5 \mathrm{mg} \mathrm{DHQ} / \mathrm{kg} / \mathrm{d}$ or $0.545 \mathrm{~g}$ of $\mathrm{DDRP} / \mathrm{kg} / \mathrm{d}$ intensified the growth performance and lowered the relative average liver weight compared to the pigs from control group. 
The increasing between 7.74-9.05\% of ABW, 27.06-30.13\% of ADG, and 12.53-15.99\% of feed to gain ratio, and decreasing of feed consumption between 5.24-13.84\%, and reduction of ALW between 10.53-21.12\%, was found.

Two supplementations didn't cause pathological changes in histological structure of pigs' liver and ovaries, and didn't influence $\mathrm{pH}$ values and proximate composition of $\mathrm{m}$. Longissimus thoracis and m. Semimebranosus.

The meat was found normal without stress-induced muscle damage and the carcasses were classified in classes $\mathrm{E}$ and $\mathrm{U}$.

Two phytonutrient supplementations contributed to reduction of LDLs by 13.27-14.29\% and stimulated increasing of blood parameters RBC, PLT, HCT, MCV, MCHC, TRIG and T CHOL.

Conflict of interest. The authors declare no conflict of interest.

\section{REFERENCES}

Anwar MN, Ravindran V, Morel PCH, Ravindran G, Cowieson AJ. Measurement of true ileal calcium digestibility in meat and bone meal for broiler chickens using the direct method. Poultry Sci. 2016;95,70-76.

AOCS. American Oil Chemists' Society. Official methods and recommended practices of the American Oil Chemists' Society, 5th Edn. Champaign, IL, USA: American Oil Chemists Society; 2004.

Artem'eva OA, Pereselkova DA, Fomichev YuP. Dihydroquercetin, the bioactive substance, to be used against pathogenic microorganisms as an alternative to antibiotics. Agric. Biol. 2015;50:513-519.

Balev D, Vlahova-Vangelova D, Mihalev K, Shikov V, Dragoev S, Nikolov V. Application of natural dietary antioxidants in broiler feeds. J. Mt. Agric. Balk. 2015;18:224-232.

Bogolyubova NV, Chabaev MG, Fomichev YuP, Tsis EYu, Semenova AA, Nekrasov RV. Ways to reduce adverse effects of stress in pigs using nutritional factors. Ukr. J. Ecol. 2019;9:239-245.

Chen JW, Zhu ZQ, Hu TX, Zhu DY. Structure-activity relationship of natural flavonoids in hydroxyl radical-scavenging effects. Acta Pharmacol. Sin. 2002;23:667-672.

Costa LB, Luciano FB, Miyada VS, Gois FD. Herbal extracts and organic acids as natural feed additives in pig diets. S. Afr. J. Anim. Sci. 2013;43:181-193.

Kevenaar ME, Themmen APN, Laven JSE, Sonntag B, Fong SL, Uitterlinden AG, de Jong FH, Pols HAP, Simoni M, Visser JA. Anti-Müllerian hormone and anti-Müllerian hormone type II receptor polymorphisms are associated with follicular phase estradiol levels in normo-ovulatory women. Human Reprod. 2007; 22:1547-1554.

Culioli J, Berri C, Mourot J. Muscle foods: consumption, composition and quality. Sci. Aliment. 2003;23:13-34.

Dragoev S, Vlahova-Vangelova D, Balev D, Bozhilov D, Dagnon S. Valorization of waste byproducts of rose oil production as feedstuff phytonutrients. Bulg. J. Agric. Sci. In press. 2021;27: Preprint:AgriRxiv2020.DOI:10.31220/osf.io/cdf9b

Fomichev Y, Nikanova L, Lashin A. The effectiveness of using dihydroquercetin (taxifolin) in animal husbandry, poultry and apiculture for prevention of metabolic disorders, higher antioxidative capacity, better resistance and realisation of a productive potential of organism. Agric. Food. 2016;4:140-159. 
Frankič T, Voljč M, Salobir J, Rezar V. Use of herbs and spices and their extracts in animal nutrition. Acta Argic. Sloven. 2009;94:95-102.

Hashemi SR, Davoodi H. Herbal plants and their derivatives as growth and health promoters in animal nutrition. Vet. Res. Commun. 2011;35:169-180.

Guil-Guerrero JL, Ramos L, Moreno C, Zúñiga-Paredes JC, Carlosama-Yépez M, Rualesa P. Plant-food by-products to improve farm-animal health. Anim. Feed Sci. Technol. 2016;220:121-135.

Kawabata K, Mukai R, Ishisaka A. Quercetin and related polyphenols: new insights and implications for their bioactivity and bioavailability. Food Func. 2015; 6:1399-1417.

Keeton JT, Hafley BS, Eddy SM, Moser CR, McManus BJ, Leffler TP. Rapid determination of moisture and fat in meats by microwave and nuclear magnetic resonance analysis. $\mathrm{J}$. AOAC Int. 2003;86:1193-1202,1210.

Kolesnik Y, Titova E, Chertkov V, Tashlitsky V, Tikhonov V, Shmatkov D. Stereoisomeric composition of two bioflavonoids from Larix sibirica. Planta Med. 2011;77,PA17.

Lebret B. Effects of feeding and rearing systems on growth, carcass composition and meat quality in pigs. Animal. 2008;2:1548-1558.

Leman A, O'Rourke N, Hatcher L, Stepanski ED. JMP for Basic Univariate and Multivariate Statistics: Methods for Researchers and Social Scientists. Second ed. Cary, NC, USA: SAS Institute Inc.; 2013.

Lesser S, Cermak R, Wolffram S. The fatty acid pattern of dietary fat influences the oral bioavailability of the flavonol quercetin in pigs. Br. J. Nutr. 2006;96,1047-1052.

Liu H, Qiu N, Ding H, Yao R. Polyphenols contents and antioxidant capacity of 68 Chinese herbals suitable for medical or food uses. Food Res. Inter. 2008;41:363-370.

Manach C, Williamson G, Morand C, Scalbert A, Rémésy C. Bioavailability and bioefficacy of polyphenols in humans. I. Review of 97 bioavailability studies. Am. J. Clin. Nutr. 2005;81:230S-242S.

Miller NJ, Ruiz-Larrea MB. Flavonoids and other plant phenols in the diet: Their significance as antioxidants. J. Nutr. Environ. Med. 2002;12: 39-51.

Nowak R, Olech M, Pecio Ł, Oleszek W. Cytotoxic, antioxidant, antimicrobial properties and chemical composition of rose petals. J. Sci. Food Agric. 2014;94:560-567.

Pieszka M, Szczurek P, Bederska-Łojewska D. The effect of dietary supplementation with dried fruit and vegetable pomaces on production parameters and meat quality in fattening pigs. Meat Sci. 2017;126:1-10.

Pitoyo FLH, Fatmawati H. The effect of quercetin to reduced triglyceride and blood glucose level in animal model diet-induced obesity. J. Med. Planta. 2012;1:36-46.

Reed BG, Carr BR. The normal menstrual cycle and the control of ovulation. In: Feingold KR, editor. Endotext: South Dartmouth, MA, USA: MDText.com, Inc.; 2000. [Updated August 5, 2018]. Available from: https://www.ncbi.nlm.nih.gov/sites/books/NBK279054/.

Schieber A, Mihalev K, Berardini N, Mollov P. Flavonol glycosides from distilled petals of Rosa damascena Mill. Z. Naturforsch. C. 2005;60: 379-384.

Škottova N, Večeřa R, Urbánek K, Váňa P, Walterová D, Cvak L. Effects of polyphenolic fraction of silymarin on lipoprotein profile in rats fed cholesterol-rich diets. Pharmacol. Res. 2003;47:17-26.

Sultana A, Nakanishi A, Roy BC, Mizunoya W, Tatsumi R, Ito T, Tabata S, Rashid H, Katayama S, Ikeuchi Y. Quality improvement of frozen and chilled beef biceps femoris with the application of salt-bicarbonate solution. Asian-Aust. J. Anim. Sci. 2008;21:903911. 
Valenzuela-Grijalva NV, Pinelli-Saavedra A, Muhlia-Almazan A, Domínguez-Díaz D, González-Ríos H. Dietary inclusion effects of phytochemicals as growth promoters in animal production. J. Anim. Sci. Technol. 2017;59:1-17.

Vlahova-Vangelova D., Balev D., Ivanova S., Nakev J., Nikolova T., Dragoev S., Gerrard D. Improving the oxidative stability of pork by antioxidant type phytonutrients. Biointerface Res. Appl. Chem. 2020;10:5624-5633.

Weidmann AE. Dihydroquercetin: More than just an impurity? Eur. J. Pharmacol. 2012;684:19-26.

Warriss PD. Animal welfare. In: Warriss PD, editor. Meat Science: An Introductory Text. Wallingford, NY, USA: CABI Publishing; 2010. pp. 151-162.

Weiser G. Laboratory technology for veterinary medicine. In: Thrall MA, Weiser G, Allison R, Campbell T. editors. Veterinary Hematology and Clinical Chemistry. Second Edn. Ames, IO, USA: John Wiley \& Sons Inc.; 2012. pp. 3-33.

Wood JD, Enser M, Fisher AV, Nute GR, Sheard PR, Richardson RI, Hughes SI, Whittington FM. Fat deposition, fatty acid composition and meat quality: A review. Meat Sci. 2008;78:343-358.

Yan L, Wang JP, Kim HJ, Meng QW, Ao X, Hong SM, Kim IH. Influence of essential oil supplementation and diets with different nutrient densities on growth performance, nutrient digestibility, blood characteristics, meat quality and faecal noxious gas content in growerfinisher pigs. Livest. Sci. 2010;128:115-122.

Young OA, West J, Hart AL, van Otterdijk FFH. A method for early determination of meat ultimate pH. Meat Sci. 2004;66:493-498. 
Table 12. Ingredients, chemical composition and energy values of basal diet

\section{Components}

Grower

Formulations

Maize, $\mathrm{g} / \mathrm{kg}$

Barley, $\mathrm{g} / \mathrm{kg}$

Wheat, $\mathrm{g} / \mathrm{kg}$

Wheat bran, $\mathrm{g} / \mathrm{kg}$

Bio-concentrate $\mathrm{BC} 14^{\mathrm{b}}, \mathrm{g} / \mathrm{kg}$

Bio-concentrate $\mathrm{BC} 16^{\mathrm{c}}, \mathrm{g} / \mathrm{kg}$

Total:
150.00

130.00

250.00

100.00

270.00

500.00

80.00

250.00

200.00

1000.00

1000.00
Finisher

\section{Calculated chemical compositions}

Moisture, $\mathrm{g} / \mathrm{kg}$

Dry matter, $\mathrm{g} / \mathrm{kg}$

Organic substances, $\mathrm{g} / \mathrm{kg}$

Crude protein, $\mathrm{g} / \mathrm{kg}$

Crude fats, $\mathrm{g} / \mathrm{kg}$

Crude ash, $\mathrm{g} / \mathrm{kg}$

Neutral detergent fibers, $\mathrm{g} / \mathrm{kg}$

Lysine, $\mathrm{g} / 100 \mathrm{~g}$

Calcium, g/100 g

Phosphorus, g/100 g
171.00

829.00

782.20

157.50

28.10

46.80

47.90

0.80

1.31

0.85
157.00

843.00

799.10

150.20

24.20

43.90

38.40

0.72

1.26

0.31

Energy intake

Digestible energy, $\mathrm{MJ} / \mathrm{kg}$ forage

Exchangeable energy, $\mathrm{MJ} / \mathrm{kg}$ forage

12.92

Legend:

a The quantities of Siberian larch dihydroquercetin or dry distilled rose petals added as supplements to the diets were calculated as $3.5 \mathrm{mg}$ dihydroquercetin/ $/ \mathrm{kg} / \mathrm{d}$ (D1); $7.5 \mathrm{mg}$ dihydroquercetin/kg/d (D2); $0.255 \mathrm{~g}$ dry distilled rose petals $/ \mathrm{kg} / \mathrm{d}(\mathrm{R} 1)$; or $0.545 \mathrm{~g}$ dry distilled rose petals $/ \mathrm{kg} / \mathrm{d}(\mathrm{R} 2)$.

${ }^{\mathrm{b}}$ The bio-concentrate BC14 contents: $312.10 \mathrm{~g} / \mathrm{kg}$ crude protein, $10.70 \mathrm{~g} / \mathrm{kg}$ crude fat, $153.00 \mathrm{~g} / \mathrm{kg}$ crude ash, $38.10 \mathrm{~g} / \mathrm{kg}$ crude fibers, $5.88 \mathrm{~g} / 100 \mathrm{~g}$ lysine, $2.79 \mathrm{~g} / 100 \mathrm{~g}$ methionine, $7.80 \mathrm{~g} / 100 \mathrm{~g}$ calcium, $2.69 \mathrm{~g} / 100 \mathrm{~g}$ phosphorus, $268 \mathrm{mg} / \mathrm{kg}$ copperas sulphate, $670 \mathrm{mg} / \mathrm{kg}$ dl- $\alpha$-tocopherol, $93800 \mathrm{UI} / \mathrm{kg}$ vitamin A, $16080 \mathrm{UI} / \mathrm{kg}$ vitamin D3, $1975.845 \mathrm{kcal} / \mathrm{kg}$ total energy

${ }^{\mathrm{c}}$ The bio-concentrate BC16 contents: $348.00 \mathrm{~g} / \mathrm{kg}$ crude protein, $17.40 \mathrm{~g} / \mathrm{kg}$ crude fat, $165.00 \mathrm{~g} / \mathrm{kg} \mathrm{g}$ crude ash, $108.30 \mathrm{~g} / \mathrm{kg}$ crude fibers, $2.26 \mathrm{~g} / 100 \mathrm{~g}$ lysine, $0.67 \mathrm{~g} / 100 \mathrm{~g}$ methionine, i.e. $1.25 \mathrm{~g} / 100 \mathrm{~g}$ methionine + cystine, $1.31 \mathrm{~g} / 100 \mathrm{~g}$ threonine, $3.66 \mathrm{~g} / 100 \mathrm{~g}$ calcium, $0.95 \mathrm{~g} / 100 \mathrm{~g}$ phosphorus, i.e. $0.67 \mathrm{~g} / 100 \mathrm{~g}$ absorbable phosphorus, $0.78 \mathrm{~g} / 100 \mathrm{~g}$ sodium, $560.00 \mathrm{mg} / \mathrm{kg}$ iron, $545.00 \mathrm{mg} / \mathrm{kg}$ zinc, $195.00 \mathrm{mg} / \mathrm{kg}$ manganese, $100.00 \mathrm{mg} / \mathrm{kg}$ copper, $4.10 \mathrm{mg} / \mathrm{kg}$ iodine, $1.50 \mathrm{mg} / \mathrm{kg}$ selenium, $0.40 \mathrm{~g} / 100 \mathrm{~g}$ antioxidants, $320.00 \mathrm{mg} / \mathrm{kg}$ vitamin E, $32500 \mathrm{UI} / \mathrm{kg}$ vitamin A, $6000 \mathrm{UI} / \mathrm{kg}$ vitamin D3. 
Table 2. Average body weight, average daily gain, feed consumption and feed to gain ratio in fattening pigs

\begin{tabular}{|c|c|c|c|c|c|c|}
\hline Parameters & $\begin{array}{c}\text { Control } \\
\text { group }(\mathrm{C})\end{array}$ & $\begin{array}{l}\text { Experimental } \\
\text { group (D1) }\end{array}$ & $\begin{array}{l}\text { Experimental } \\
\text { group (D2) }\end{array}$ & $\begin{array}{l}\text { Experimental } \\
\text { group (R1) }\end{array}$ & $\begin{array}{l}\text { Experimental } \\
\text { group (R2) }\end{array}$ & Significance \\
\hline $\begin{array}{l}\text { Initial average body weight (ABW), } \\
\text { kg } 3 \text { August 2017, Pigs at } 155 \text { days of age }\end{array}$ & $72.750 \pm 1.988$ & $72.500 \pm 1.851$ & $72.500 \pm 1.625$ & $72.625 \pm 1.990$ & $72.125 \pm 2.231$ & N.S. \\
\hline $\begin{array}{l}\text { Final average body weight (ABW), } \\
\text { kg } 17 \text { September } 2017 \text {, Pigs at } 200 \text { days of } \\
\text { age }\end{array}$ & $\begin{array}{c}105.000 \pm 4.255^{\mathrm{ab}} \\
(100.00 \%)\end{array}$ & $\begin{array}{c}114.500 \pm 2.570^{\mathrm{a}} \\
(109.05 \%)\end{array}$ & $\begin{array}{l}109.000 \pm 2.449 \\
(103.81 \%)\end{array}$ & $\begin{array}{l}109.875 \pm 2.793 \\
\quad(104.64 \%)\end{array}$ & $\begin{array}{l}113.125 \pm 1.551^{\mathrm{b}} \\
\quad(107.74 \%)\end{array}$ & $\mathrm{p}<0.05$ \\
\hline $\begin{array}{l}\text { Average daily gain (ADG) on the end } \\
\text { of the experiment, } \mathrm{kg} / \mathrm{pig} / \mathrm{day}\end{array}$ & $\begin{array}{c}0.717 \pm 0.062^{\mathrm{ac}} \\
100.00 \%\end{array}$ & $\begin{array}{c}0.933 \pm 0.023^{c} \\
130.13 \%\end{array}$ & $\begin{array}{c}0.811 \pm 0.055 \\
113.11 \%\end{array}$ & $\begin{array}{c}0.828 \pm 0.051^{\mathrm{b}} \\
115.48 \%\end{array}$ & $\begin{array}{l}0.911 \pm 0.036^{\mathrm{ab}} \\
127.06 \%\end{array}$ & $\mathrm{p}<0.01$ \\
\hline $\begin{array}{l}\text { Feed consumption, kg/pig/day } \\
\text { (3 August } 2017 \text { - } 17 \text { September 2017) }\end{array}$ & $\begin{array}{l}2.941 \pm 0.110^{\mathrm{d}} \\
100.00 \%\end{array}$ & $\begin{array}{c}3.348 \pm 0.050^{\mathrm{ad}} \\
113.84 \%\end{array}$ & $\begin{array}{c}3.095 \pm 0.069^{\mathrm{a}} \\
105.24 \%\end{array}$ & $\begin{array}{c}3.099 \pm 0.079 \\
105.37 \%\end{array}$ & $\begin{array}{l}3.139 \pm 0.06 \\
106.73 \%\end{array}$ & $\mathrm{p}<0.05$ \\
\hline $\begin{array}{l}\text { Feed to gain ratio, for the whole } \\
\text { experimental period, } \mathrm{kg}\end{array}$ & $\begin{array}{c}4.102 \pm 0.233^{\mathrm{d}} \\
100.00 \%\end{array}$ & $\begin{array}{c}3.588 \pm 0.064^{\mathrm{d}} \\
87.47 \%\end{array}$ & $\begin{array}{c}3.816 \pm 0.210 \\
93.03 \%\end{array}$ & $\begin{array}{l}3.743 \pm 0.210^{\mathrm{a}} \\
91.29 \%\end{array}$ & $\begin{array}{c}3.446 \pm 0.107^{\mathrm{ad}} \\
84.01 \%\end{array}$ & $\mathrm{p}<0.05$ \\
\hline
\end{tabular}

\section{Legend:}

Control group (C) pigs received a typical commercial diet.

Experimental group (D1) fed with a commercial diet with addition of $3.5 \mathrm{mg}$ dihydroquercetin/ $\mathrm{kg}$ live weight per day;

Experimental group (D2) fed with a commercial diet with addition of $7.5 \mathrm{mg}$ dihydroquercetin/kg live weight per day;

Experimental group (R1) fed with a commercial diet with addition of $0.255 \mathrm{~g}$ dry distilled rose petals/kg live weight per day;

Experimental group (R2) fed with a commercial diet with addition of $0.545 \mathrm{~g}$ dry distilled rose petals/kg live weight per day

Results are presented as mean values \pm standard error

Statistically significant differences are marked with common letters: a,b,c $-p<0.05 ;{ }^{d}-p<0.01$ 
Table 3. Blood tests parameters in fattening pigs

\begin{tabular}{|c|c|c|c|c|c|c|c|c|c|c|}
\hline \multirow[t]{2}{*}{ Indicator } & \multirow{2}{*}{$\begin{array}{l}\text { At the beginning } \\
\text { of the experiment } \\
3 \text { August } 2017\end{array}$} & \multicolumn{5}{|c|}{$\begin{array}{c}\text { At the end of the experiment } \\
17 \text { September } 2017\end{array}$} & \multicolumn{4}{|c|}{ Significance } \\
\hline & & $\begin{array}{l}\text { Control } \\
\text { group C }\end{array}$ & $\begin{array}{l}\text { Experimental } \\
\text { group D1 }\end{array}$ & $\begin{array}{l}\text { Experimental } \\
\text { group D2 }\end{array}$ & $\begin{array}{l}\text { Experimental } \\
\text { group R1 }\end{array}$ & $\begin{array}{l}\text { Experimental } \\
\text { group R2 }\end{array}$ & $\begin{array}{l}\text { Root-mean- } \\
\text { square error } \\
\text { (RMSE) }\end{array}$ & Interval & Group & $\begin{array}{c}\text { Interval x } \\
\text { Group }\end{array}$ \\
\hline $\begin{array}{l}\text { WBC } \\
\text { leukocytes }\end{array}$ & $28.82^{\mathrm{a}}$ & 20.41 & 20.17 & 21.65 & 19.18 & 19.89 & 3.35 & $*$ & NS & $\mathrm{NS}$ \\
\hline $\begin{array}{l}\text { RBC } \\
\text { erythrocytes }\end{array}$ & $6.21^{\mathrm{b}}$ & $6.20^{\mathrm{ab}}$ & $6.47^{\mathrm{b}}$ & $6.15^{\mathrm{ab}}$ & $6.30^{\mathrm{ab}}$ & $6.13^{\mathrm{a}}$ & 0.39 & $* * *$ & $*$ & NS \\
\hline $\begin{array}{l}\text { HGL } \\
\text { hemoglobin }\end{array}$ & $113.87^{\mathrm{ab}}$ & 113.50 & 115.37 & 114.16 & 118.08 & 112.75 & 7.07 & $*$ & NS & NS \\
\hline $\begin{array}{l}\mathrm{HCT} \\
\text { hematocrit }\end{array}$ & $0.42^{\mathrm{a}}$ & $0.41^{\mathrm{abc}}$ & $0.44^{\mathrm{a}}$ & $0.38^{\mathrm{bc}}$ & $0.43^{\mathrm{ab}}$ & $0.36^{\mathrm{c}}$ & 0.40 & $*$ & $* * *$ & NS \\
\hline $\begin{array}{l}\text { MCV } \\
\text { mean red blood cell count }\end{array}$ & $67.43^{\mathrm{a}}$ & $66.06^{\mathrm{a}}$ & $68.57^{\mathrm{a}}$ & $63.11^{\mathrm{ab}}$ & $67.87^{\mathrm{a}}$ & $58.82^{\mathrm{b}}$ & 8.24 & $*$ & $* * *$ & NS \\
\hline $\begin{array}{l}\text { MCH } \\
\text { mean hemoglobin content } \\
\text { in erythrocytes }\end{array}$ & $18.33^{\mathrm{ab}}$ & 18.30 & 18.31 & 18.64 & 18.26 & 18.31 & 0.57 & $*$ & NS & NS \\
\hline $\begin{array}{l}\text { MCHC mean haemo- } \\
\text { globin concentration in } \\
\text { erythrocytes }\end{array}$ & $279.22^{b}$ & $281.50^{\mathrm{bc}}$ & $313.95^{\mathrm{a}}$ & $275.58^{\mathrm{bc}}$ & $300.08^{\mathrm{ab}}$ & $273.00^{c}$ & 32.58 & $*$ & $* * *$ & NS \\
\hline $\begin{array}{l}\text { RWD erythrocyte } \\
\text { distribution width accordir } \\
\text { to their volume }\end{array}$ & $18.25^{\mathrm{b}}$ & $19.22^{\mathrm{b}}$ & $24.14^{\mathrm{a}}$ & $18.20^{\mathrm{b}}$ & $21.28^{\mathrm{ab}}$ & $18.04^{\mathrm{b}}$ & 5.15 & $*$ & $* * *$ & NS \\
\hline $\begin{array}{l}\text { PLT } \\
\text { platelets }\end{array}$ & $519.40^{\mathrm{a}}$ & $418.87^{\mathrm{ab}}$ & $484.29^{\mathrm{a}}$ & $427.58^{\mathrm{ab}}$ & $429.66^{\mathrm{ab}}$ & $333.66^{\mathrm{b}}$ & 153.48 & $* * *$ & $*$ & NS \\
\hline $\begin{array}{l}\text { MPV } \\
\text { mean platelets volume }\end{array}$ & 6.68 & 7.01 & 7.48 & 7.20 & 7.15 & 6.12 & 2.81 & NS & NS & NS \\
\hline $\begin{array}{l}\text { GLU } \\
\text { glucose }\end{array}$ & $4.41^{\mathrm{ab}}$ & 4.56 & 4.41 & 4.13 & 4.42 & 4.56 & 0.59 & $* *$ & NS & NS \\
\hline $\begin{array}{l}\text { T CHOL } \\
\text { total cholesterol }\end{array}$ & 2.44 & $2.21^{\mathrm{b}}$ & $2.51^{\mathrm{a}}$ & $2.38^{\mathrm{ab}}$ & $2.45^{\mathrm{a}}$ & $2.35^{\mathrm{ab}}$ & 0.30 & NS & $*$ & NS \\
\hline $\begin{array}{l}\text { TRIG } \\
\text { triglycerides }\end{array}$ & $1.26^{\mathrm{a}}$ & $1.11^{\mathrm{c}}$ & $1.31^{\mathrm{a}}$ & $1.16^{\mathrm{bc}}$ & $1.23^{\mathrm{ab}}$ & $1.12^{\mathrm{bc}}$ & 0.15 & $* * *$ & $* * *$ & NS \\
\hline $\begin{array}{l}\text { LDL- } \\
\text { cholesterol }\end{array}$ & 0.94 & $0.98^{\mathrm{a}}$ & $0.84^{\mathrm{b}}$ & $0.98^{\mathrm{a}}$ & $0.85^{b}$ & $0.92^{\mathrm{ab}}$ & 0.18 & NS & $* *$ & NS \\
\hline $\begin{array}{l}\text { HDL- } \\
\text { cholesterol }\end{array}$ & $0.53^{\mathrm{a}}$ & 0.45 & 0.48 & 0.48 & 0.44 & 0.53 & 0.13 & $*$ & NS & NS \\
\hline $\begin{array}{l}\text { Estradiol, } \\
\mathrm{pg} / \mathrm{ml}\end{array}$ & $\begin{array}{c}\text { Not studied. The pigs have } \\
\text { not reached puberty }\end{array}$ & $67.225^{\mathrm{d}}$ & $26.900^{\mathrm{bc}}$ & $32.615^{\mathrm{c}}$ & $27.485^{\mathrm{bc}}$ & $8.650^{\mathrm{a}}$ & 4.027 & $*$ & NS & $*$ \\
\hline
\end{tabular}

Legend: The statistical analysis was performed using two way ANOVA. The significance for the influence of the factors is: *p $<0.05 ; * * p<0.01 ; * * * p<0.001$. The presence of significant differences between the means was determined by Tukey post-hoc comparisons and was denoted by different letters. 
Table 4. Lean meat content in the carcases and pigs' liver weight

\begin{tabular}{|c|c|c|c|c|c|c|}
\hline Parameters & $\begin{array}{l}\text { Control } \\
\text { group C }\end{array}$ & $\begin{array}{l}\text { Experimental } \\
\text { group D1 }\end{array}$ & $\begin{array}{l}\text { Experimental } \\
\text { group D2 }\end{array}$ & $\begin{array}{l}\text { Experimental } \\
\text { group R1 }\end{array}$ & $\begin{array}{l}\text { Experimental } \\
\text { group R2 }\end{array}$ & Significance \\
\hline \multicolumn{7}{|c|}{ Percentage of lean meat in the carcases } \\
\hline $\mathrm{X}_{1}, \mathrm{~mm}$ & $23.37 \pm 2.53$ & $24.25 \pm 1.46^{\mathrm{a}}$ & $19.75 \pm 0.62^{\mathrm{a}}$ & $22.37 \pm 2.17$ & $17.50 \pm 2.46$ & $\mathrm{p}<0.05$ \\
\hline $\mathrm{X}_{2}, \mathrm{~mm}$ & $18.37 \pm 2.75$ & $19.37 \pm 2.17$ & $17.12 \pm 1.65$ & $17.62 \pm 2.22$ & $17.35 \pm 1.77$ & N.S. \\
\hline $\mathrm{X}_{3}, \mathrm{~mm}$ & $51.00 \pm 1.44^{\mathrm{a}}$ & $58.87 \pm 2.17^{\mathrm{a}}$ & $54.62 \pm 2.47$ & $53.37 \pm 2.47$ & $53.00 \pm 1.62$ & $\mathrm{p}<0.05$ \\
\hline Lean meat, $\%$ & $53.39 \pm 1.76$ & $52.83 \pm 1.24$ & $55.07 \pm 0.65$ & $54.03 \pm 1.28$ & $55.01 \pm 1.00$ & N.S. \\
\hline \multicolumn{7}{|c|}{ Liver weight, $\mathrm{g}$} \\
\hline Male pigs & $1831.500 \pm 86.97^{\mathrm{e}}$ & $1671.330 \pm 62.860^{b}$ & $1814.500 \pm 116.760^{\mathrm{e}}$ & $1408.500 \pm 154.980^{\mathrm{a}}$ & $1805.200 \pm 109.480^{\mathrm{e}}$ & $\mathrm{p}<0.05$ \\
\hline Female pigs & $1681.330 \pm 124.330^{\mathbf{b}}$ & $1695.000 \pm 93.710^{c}$ & $1694.000 \pm 90.500^{c}$ & $1440.500 \pm 34.650^{\mathrm{a}}$ & $1714.500 \pm 143.540^{d}$ & $\mathrm{p}<0.05$ \\
\hline $\begin{array}{l}\text { Average between } \\
\text { males and females }\end{array}$ & $1725.500 \pm 125.450^{d}$ & $1683.165 \pm 78.285^{b}$ & $1754.250 \pm 103.630^{\mathrm{e}}$ & $1424.500 \pm 94.815^{\mathrm{a}}$ & $1759.850 \pm 126.510^{\mathrm{e}}$ & $\mathrm{p}<0.01$ \\
\hline $\begin{array}{l}\text { Ratio average liver } \\
\text { weight (ALW)/final } \\
\text { ABW x } 100, \%\end{array}$ & $1.643 \% \pm 0.029^{\mathbf{a b}}$ & $1.470 \% \pm 0.030^{\mathbf{b}}$ & $1.609 \% \pm 0.042$ & $1.296 \% \pm 0.034^{\mathrm{a}}$ & $1.554 \% \pm 0.082$ & $\mathrm{p}<0.01$ \\
\hline
\end{tabular}

Legend:

The significant differences were indicated by different letters: ${ }^{\mathrm{a}, \mathrm{b}}-*^{*} \mathrm{p}<0.05 ;{ }^{\mathrm{c}}-{ }^{* *} \mathrm{p}<0.01$.

The statistical analysis was performed by Kruskall-Wallice $(\mathrm{p}<0.05)$, due to abnormal distribution of dispersions. ( $\mathrm{x}$ means \pm SD standard deviation).

$\mathrm{LM}=67.13-0.3284 \mathrm{X} 1-0.3725 \mathrm{X} 2+0.01515 \mathrm{X} 3$ where:

LM - percentage of lean meat, \%;

$\mathrm{X} 1$ - thickness of the fat and skin measured between the $3 \mathrm{rd}$ and 4 th lumbar vertebrae at $7 \mathrm{~cm}$ laterally, $\mathrm{mm}$;

$\mathrm{X} 2$ - thickness of the fat and skin measured between the $3 \mathrm{rd}$ and 4 th rib at $7 \mathrm{~cm}$ laterally, $\mathrm{mm}$;

$\mathrm{X} 3$ - thickness of $\mathrm{m}$. Longissimus thoracis between $3 \mathrm{rd}$ and $4 \mathrm{th}$ rib at $7 \mathrm{~cm}$ laterally, $\mathrm{mm}$. 
Table 5. $\mathrm{pH}$ на of pork m. Longissimus thoracis and m. Semimembranosus during 7 days storage at $0-4^{\circ} \mathrm{C}$

\begin{tabular}{|c|c|c|c|c|c|c|}
\hline Parameters & $\begin{array}{c}\text { Control group } \\
\mathrm{C}\end{array}$ & $\begin{array}{c}\text { Experimental } \\
\text { group D1 }\end{array}$ & $\begin{array}{c}\text { Experimental } \\
\text { group D2 }\end{array}$ & $\begin{array}{c}\text { Experimental } \\
\text { group R1 }\end{array}$ & $\begin{array}{l}\text { Experimental } \\
\text { group R2 }\end{array}$ & Significance \\
\hline \multicolumn{7}{|c|}{ m. Longissimus thoracis } \\
\hline $\begin{array}{l}\mathrm{pH}_{1}(45 \mathrm{~min}) \\
\mathrm{pH}_{2}(24 \mathrm{~h}) \\
\mathrm{pH}_{3}(7 \mathrm{~d})\end{array}$ & $\begin{array}{c}6.25 \pm 0.02 \\
6.00 \pm 0.05^{b} \\
6.11 \pm 0.03\end{array}$ & $\begin{array}{c}6.21 \pm 0.02 \\
5.88 \pm 0.01^{\mathrm{a}} \\
6.09 \pm 0.02\end{array}$ & $\begin{array}{c}6.19 \pm 0.04 \\
5.92 \pm 0.02^{\mathrm{ab}} \\
6.12 \pm 0.03\end{array}$ & $\begin{array}{c}6.15 \pm 0.04 \\
5.89 \pm 0.03^{\mathbf{a b}} \\
6.13 \pm 0.05\end{array}$ & $\begin{array}{c}6.28 \pm 0.05 \\
5.85 \pm 0.02^{\mathrm{a}} \\
6.07 \pm 0.03\end{array}$ & $\begin{array}{l}\text { N.S. } \\
\mathrm{p}<0.01 \\
\text { N.S. }\end{array}$ \\
\hline \multicolumn{7}{|c|}{ m. Semimembranosus } \\
\hline $\begin{array}{l}\mathrm{pH}_{1}(45 \mathrm{~min}) \\
\mathrm{pH}_{2}(24 \mathrm{~h}) \\
\mathrm{pH}_{3}(7 \mathrm{~d})\end{array}$ & $\begin{array}{c}6.21 \pm 0.04 \\
5.70 \pm 0.03^{b} \\
6.01 \pm 0.04\end{array}$ & $\begin{array}{c}6.14 \pm 0.03 \\
5.60 \pm 0.04^{\mathrm{a}} \\
5.98 \pm 0.03\end{array}$ & $\begin{array}{c}6.13 \pm 0.03 \\
5.69 \pm 0.05^{\mathrm{ab}} \\
6.00 \pm 0.05\end{array}$ & $\begin{array}{c}6.10 \pm 0.05 \\
5.71 \pm 0.01^{\mathbf{b}} \\
6.03 \pm 0.02\end{array}$ & $\begin{array}{l}6.20 \pm 0.06 \\
5.61 \pm 0.02^{\mathrm{a}} \\
5.99 \pm 0.01\end{array}$ & $\begin{array}{c}\text { N.S. } \\
p<0.05 \\
\text { N.S. }\end{array}$ \\
\hline
\end{tabular}

\section{Legend:}

The statistical analysis was performed by ANOVA. Post-hoc comparisons of experimental treatments with control by Dunnett $(* \mathrm{p}<0.05)$.

The significant differences were indicated by different letters: ${ }^{a, b}-* p<0.05$ 
Table 6. Proximate composition of m. Longissimus thoracis and m. Semimembranosus $24 \mathrm{~h}$ post mortem $\left(0-4^{\circ} \mathrm{C}\right)$

\begin{tabular}{|c|c|c|c|c|c|c|}
\hline Parameters & $\begin{array}{l}\text { Control } \\
\text { group C }\end{array}$ & $\begin{array}{l}\text { Experimental } \\
\text { group D1 }\end{array}$ & $\begin{array}{l}\text { Experimental } \\
\text { group D2 }\end{array}$ & $\begin{array}{l}\text { Experimental } \\
\text { group R1 }\end{array}$ & $\begin{array}{l}\text { Experimental } \\
\text { group R2 }\end{array}$ & Significance \\
\hline \multicolumn{7}{|c|}{ m. Longissimus thoracis } \\
\hline Moisture, g/100 g & $71.18 \pm 0.72$ & $71.72 \pm 1.55$ & $72.29 \pm 0.40$ & $71.37 \pm 1.05$ & $72.07 \pm 1.19$ & NS \\
\hline Dry mater, g/100 g & $28.81 \pm 0.72$ & $28.27 \pm 1.55$ & $27.71 \pm 0.40$ & $28.62 \pm 1.05$ & $27.92 \pm 1.19$ & NS \\
\hline Proteins, $g / 100 \mathrm{~g}$ & $22.30 \pm 0.61$ & $21.94 \pm 0.95$ & $20.91 \pm 0.28$ & $21.89 \pm 0.72$ & $22.04 \pm 1.14$ & NS \\
\hline Fats, $g / 100 \mathrm{~g}$ & $5.43 \pm 0.76$ & $5.27 \pm 0.67$ & $5.76 \pm 0.43$ & $5.68 \pm 0.55$ & $5.12 \pm 0.24$ & NS \\
\hline Ash, g/100 g & $1.09 \pm 0.03$ & $1.06 \pm 0.04$ & $1.04 \pm 0.02$ & $1.06 \pm 0.03$ & $1.06 \pm 0.05$ & NS \\
\hline \multicolumn{7}{|c|}{ m. Semimembranosus } \\
\hline Moisture, g/100 g & $69.97 \pm 1.03$ & $70.36 \pm 1.21$ & $71.22 \pm 0.77$ & $70.05 \pm 1.11$ & $71.01 \pm 1.04$ & NS \\
\hline Dry mater, $\mathrm{g} / 100 \mathrm{~g}$ & $30.03 \pm 0.96$ & $29.64 \pm 1.15$ & $28.78 \pm 1.19$ & $29.95 \pm 1.04$ & $28.99 \pm 1.21$ & NS \\
\hline Proteins, $g / 100 \mathrm{~g}$ & $23.89 \pm 0.73$ & $23.67 \pm 0.99$ & $22.79 \pm 0.82$ & $23.72 \pm 0.76$ & $22.99 \pm 0.94$ & NS \\
\hline Fats, $g / 100 \mathrm{~g}$ & $5.16 \pm 0.81$ & $5.02 \pm 0.64$ & $5.06 \pm 0.51$ & $5.23 \pm 0.83$ & $5.01 \pm 0.38$ & NS \\
\hline Ash, g/100 g & $0.98 \pm 0.12$ & $0.95 \pm 0.06$ & $0.93 \pm 0.05$ & $1.00 \pm 0.10$ & $0.99 \pm 0.09$ & NS \\
\hline
\end{tabular}

Legend:

The significant differences were indicated by different letters $\mathrm{a}, \mathrm{b} * \mathrm{p}<0.05$. The statistical analysis was performed by ANOVA. 


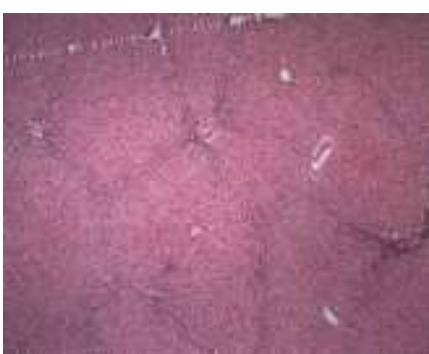

Liver

Control group (C)

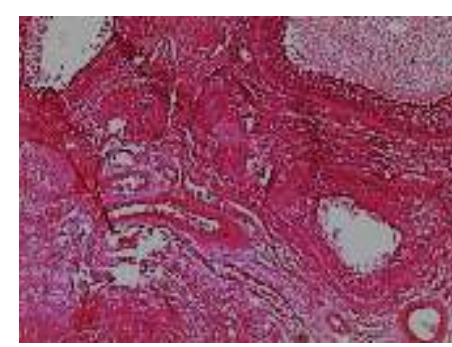

Ovaries

Control group $(\mathrm{C})$

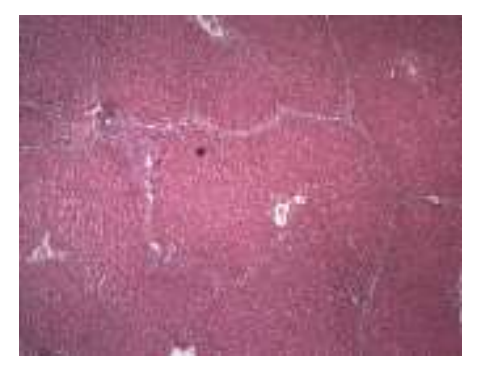

Liver

Experimental group (D1)

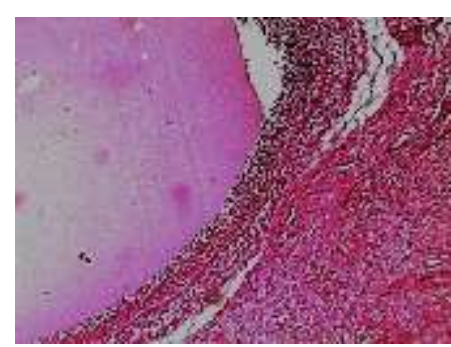

Ovaries

Experimental group (D1)

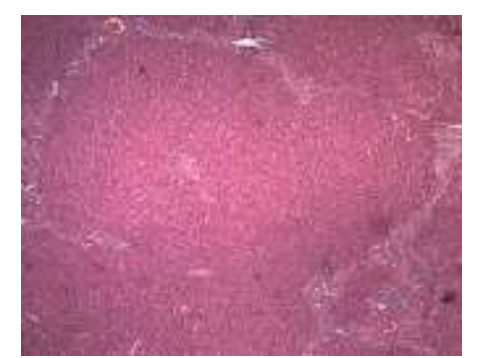

Liver

Experimental group (D2)

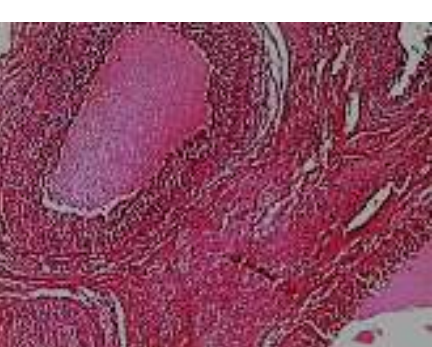

Ovaries

Experimental group (D2)

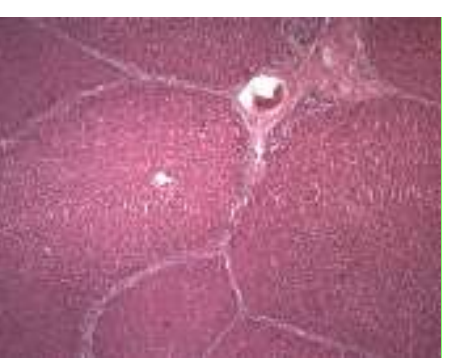

Liver

Experimental group (R1)

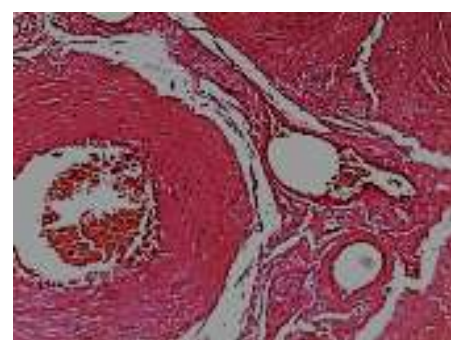

Ovaries

Experimental group (R1)

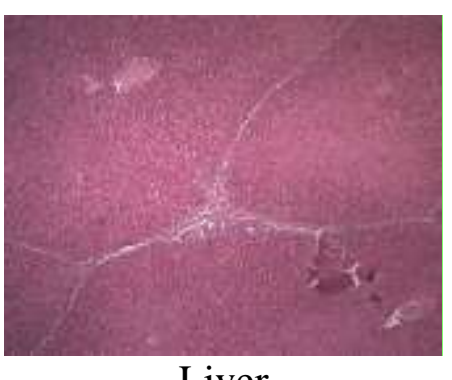

Liver

Experimental group (R2)

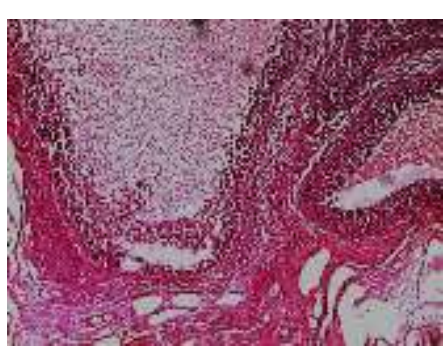

Ovaries

Experimental group (R2)

Figure 1. Histological structure of pigs' liver and ovaries (contrasted with hematoxylin - eosin; magnification x 100) 